\title{
Chemical composition and nutritional value of different wheat cultivars for broiler chickens*
}

\author{
J. Barteczko ${ }^{1,3}$, R. Augustyn ${ }^{1}$, O. Lasek ${ }^{1}$ and S. Smulikowska ${ }^{2}$ \\ ${ }^{1}$ University of Agriculture in Krakow, Department of Animal Nutrition \\ Al. Mickiewicza 24/28, 30-059 Kraków, Poland \\ ${ }^{2}$ The Kielanowski Institute of Animal Physiology and Nutrition, \\ Polish Academy of Sciences \\ 05-110 Jabłonna, Poland
}

(Received 4 September 2008; revised version 17 October 2008; accepted 23 January 2009)

\begin{abstract}
The experiment was carried out on 90 Ross 308 broiler chickens (9 groups of 10 birds each) kept in individual cages. Nine diets based on Polish wheat (Triticum aestivum) cultivars: Zebra, Bryza, Vinjett, Torka, Rysa, Mikula, Turnia, Satyna and Bombona were prepared. The diets contained $732.6 \mathrm{~g} / \mathrm{kg}$ wheat grain, soyabean meal, fish meal, lysine, methionine, vitamins and minerals. Broilers were provided experimental diets ad libitum from 14 to 42 days of age. Performance was measured, and on the last week of the experiment a marker was added to the diets, excreta were collected, analysed, and nutrient digestibility and metabolizable energy value were calculated. After completion of the experiment, jejunal digesta $\mathrm{pH}$ and viscosity were measured. Jejunal digesta viscosity was higher in birds fed diets with Bryza and Satyna cvs. than with the remaining cultivars, while apparent protein digestibility was $67.9 \%$ in birds fed diets with Rysa and Bombona cvs., and 84.6 on average, in birds fed diets with Zebra, Torka, Mikula, Turnia and Satyna cvs. Wheat cultivar neither influenced the $\mathrm{AME}_{\mathrm{N}}$ value of diets, which averaged $12.5 \mathrm{MJ} /$ $\mathrm{kg}$, nor body weight gain, while the feed conversion ratio was $6 \%$ better, on average, in birds fed diets with cultivars of lower viscosity (Zebra, Vinjett, Torka and Turnia) in comparison with diets based on the remaining cultivars $(\mathrm{P}<0.05)$.
\end{abstract}

KEY WORDS: broiler chickens, wheat cultivar, apparent protein digestibility, $\mathrm{AME}_{\mathrm{N}}$, viscosity, jejunal digesta

\footnotetext{
* Supported by Ministry of Science and Higher Education, Grant No. 2PO6Z 04629

${ }^{3}$ Corresponding author: e-mail: rzbartec@cyf-kr.edu.pl
} 


\section{INTRODUCTION}

At least several hundred wheat cultivars are used throughout the world, however, most of the technological parameters that describe the quality of seeds have been defined for human utilization (Carré et al., 2007). In Europe wheat is commonly used in poultry diets, but the nutritional potential of wheat cultivars in poultry feeding remains unknown. It is generally admitted that there is no problem when wheat is given to adult birds, but effects in broiler production are often unsatisfactory due to the variability of energy value between cultivars (McCracken and Quintin, 2000; Steenfeld, 2001; Pirgozliev et al., 2003; Carré et al., 2007). The content and physico-chemical characteristics of non-starch polysaccharides (NSP) can influence intestinal viscosity, nutrient digestibility and apparent metabolizable energy value $\left(\mathrm{AME}_{\mathrm{N}}\right)$ in chickens (Mollah et al., 1983; Dusel et al., 1997; Pirgozliev et al., 2003).

The aim of the study was to determine the metabolizable energy value and nutrient utilization of diets based on different wheat cultivars in broiler chickens. Furthermore, the correlations between the content of different fractions of dietary fibre in wheat cultivars and characteristics of intestinal parameters ( $\mathrm{pH}$, viscosity), length of intestine and gizzard weight in chickens were determined.

\section{MATERIAL AND METHODS}

Nine Polish wheat cultivars: Zebra, Bryza, Vinjett, Torka, Rysa, Mikula, Turnia, Satyna and Bombona were used (Table 1). All wheat cultivars were grown on an experimental farm near Krakow (Poland) and harvested in the year 2005. Nine

Table 1. Nutrient composition (g/kg), gross energy (GE) content and the weight of 1000 grain $(\mathrm{GW})$ of wheat cultivars

\begin{tabular}{lccccccccc}
\hline \multirow{2}{*}{ Item } & \multicolumn{8}{c}{ Wheat cultivar } \\
\cline { 2 - 10 } & Zebra & Bryza & Vinjett & Torka & Rysa & Mikula & Turnia & Satyna Bombona \\
\hline Dry matter & 864 & 868 & 861 & 861 & 875 & 859 & 863 & 861 & 862 \\
Crude ash & 16.7 & 16.2 & 16.2 & 14.5 & 15.7 & 18.5 & 14.8 & 15.6 & 15.8 \\
Crude protein & 118 & 120 & 120 & 102 & 132 & 117 & 106 & 104 & 126 \\
Crude fat & 14.2 & 13.9 & 16.9 & 9.1 & 22.6 & 10.3 & 19.6 & 10.7 & 15.3 \\
N-free extractives & 693 & 698 & 686 & 715 & 689 & 696 & 705 & 707 & 686 \\
Crude fibre & 22.0 & 19.4 & 23.0 & 20.5 & 14.9 & 17.4 & 17.2 & 23.6 & 19.0 \\
ADF & 33.2 & 43.4 & 36.5 & 30.8 & 30.4 & 42.1 & 26.4 & 32.6 & 28.6 \\
NDF & 112 & 131 & 103 & 94 & 101 & 126 & 105 & 135 & 96 \\
IDF & 100 & 92 & 94 & 93 & 97 & 99 & 95 & 112 & 93 \\
SDF & 15.9 & 16.2 & 16.0 & 19.1 & 16.0 & 20.9 & 14.7 & 8.8 & 16.7 \\
GE, MJ/kg & 15.9 & 16.0 & 15.7 & 15.7 & 16.4 & 15.7 & 16.0 & 15.7 & 15.9 \\
GW, g $^{1}$ & 46 & 40 & 43 & 45 & 38 & 52 & 42 & 46 & 48 \\
\hline
\end{tabular}

${ }^{1}$ - insoluble dietary fibre; ${ }^{2}$ - soluble dietary fibre 
experimental diets were prepared (Table 2). The diets were based on wheat grain and were supplemented with soyabean meal, fish meal, L-lysine, DL-methionine, vitamins and minerals to satisfy the nutrient requirements of broilers according to Smulikowska and Rutkowski (2005). The experiment was carried out on 90 Ross 308 broiler chickens ( 9 groups, 5 males and 5 females per group) aged 14 days with an average initial body weight of $430 \mathrm{~g}$. The birds were kept in individual balance cages and fed experimental diets in mash form ad libitum from day 14 to 42 of life. Feed intake and body weight were measured in weekly intervals and body weight gain (BWG) and feed conversion ratio (FCR) were calculated.

Between day 33 and 42 of life the chickens were fed diets of the same composition (Table 2) but containing $3 \mathrm{~g} \mathrm{Cr}_{2} \mathrm{O}_{3}$ per $\mathrm{kg}$ added as a marker on top

Table 2. Ingredients and nutrient composition of the experimental diets, $\mathrm{g} / \mathrm{kg}$

\begin{tabular}{|c|c|c|c|c|c|c|c|c|c|}
\hline \multirow{2}{*}{ Item } & \multicolumn{9}{|c|}{ Dietary treatment - wheat cultivar } \\
\hline & Zebra & Bryza & Vinjett & Torka & Rysa & Mikula & Turnia & Satyna & Bombona \\
\hline \multicolumn{10}{|l|}{ Component } \\
\hline wheat & 732.6 & 732.6 & 732.6 & 732.6 & 732.6 & 732.6 & 732.6 & 732.6 & 732.6 \\
\hline soyabean meal & 150 & 150 & 150 & 150 & 150 & 150 & 150 & 150 & 150 \\
\hline fish meal & 80 & 80 & 80 & 80 & 80 & 80 & 80 & 80 & 80 \\
\hline $\begin{array}{l}\text { monocalcium } \\
\text { phosphate }\end{array}$ & 8 & 8 & 8 & 8 & 8 & 8 & 8 & 8 & 8 \\
\hline limestone & 18 & 18 & 18 & 18 & 18 & 18 & 18 & 18 & 18 \\
\hline $\mathrm{NaCl}$ & 3 & 3 & 3 & 3 & 3 & 3 & 3 & 3 & 3 \\
\hline L-lysine & 1.2 & 1.2 & 1.2 & 1.2 & 1.2 & 1.2 & 1.2 & 1.2 & 1.2 \\
\hline DL-methionine & 2.2 & 2.2 & 2.2 & 2.2 & 2.2 & 2.2 & 2.2 & 2.2 & 2.2 \\
\hline $\begin{array}{l}\text { vitamin-mineral } \\
\text { premix }\end{array}$ & 5 & 5 & 5 & 5 & 5 & 5 & 5 & 5 & 5 \\
\hline \multicolumn{10}{|l|}{ Analysed } \\
\hline dry matter & 871 & 875 & 874 & 876 & 883 & 876 & 878 & 871 & 873 \\
\hline organic matter & 811 & 816 & 814 & 815 & 824 & 818 & 819 & 812 & 813 \\
\hline crude ash & 59.8 & 59.1 & 59.5 & 61.1 & 59.1 & 58.2 & 58.4 & 59.0 & 59.2 \\
\hline crude protein & 203 & 203 & 206 & 204 & 215 & 193 & 196 & 195 & 210 \\
\hline crude fat & 19.7 & 19.3 & 21.8 & 17.0 & 26.0 & 16.1 & 23.8 & 17.3 & 20.6 \\
\hline $\mathrm{N}$-free extractives & 567 & 575 & 565 & 577 & 567 & 589 & 582 & 579 & 564 \\
\hline crude fibre & 20.5 & 18.2 & 21.3 & 17.3 & 15.4 & 19.5 & 17.1 & 21.8 & 18.9 \\
\hline $\mathrm{ADF}$ & 34.3 & 41.8 & 36.7 & 40.8 & 32.3 & 32.6 & 29.3 & 33.9 & 30.9 \\
\hline NDF & 97.5 & 115 & 90.9 & 108 & 90 & 84.7 & 92.5 & 114 & 85.8 \\
\hline $\mathrm{IDF}^{1}$ & 89.4 & 90.9 & 90.1 & 94.8 & 89.9 & 94.0 & 92.4 & 104 & 89.0 \\
\hline $\mathrm{SDF}^{1}$ & 12.2 & 10.8 & 11.7 & 11.6 & 10.5 & 14.0 & 11.8 & 15.3 & 18.7 \\
\hline $\mathrm{GE}, \mathrm{kcal} / \mathrm{kg}$ & 16.0 & 15.9 & 16.1 & 16.0 & 16.4 & 15.9 & 16.1 & 15.9 & 16.1 \\
\hline
\end{tabular}

1,2 - see Table 1 
of the diet. Feed intake was measured on a daily basis, and between day 38 to 41 excreta from each bird were collected twice a day, pooled, and kept frozen at $-18^{\circ} \mathrm{C}$ until analysis.

\section{Chemical analysis}

At the age of 42 days all of the birds were weighed and sacrificed. After opening the abdomen the intestinal tract was exposed, the gizzard was excised and weighed, and the length of the jejunum and ileum was measured. The content of the jejunum (from the end of the duodenum to Meckel's diverticulum) was collected and $\mathrm{pH}$ was immediately measured with the use of a Mera Elwro $\mathrm{N}$ $517 \mathrm{pH}$-meter. The digesta was then centrifuged at $10000 \mathrm{~g}$ for $10 \mathrm{~min}$ at $4^{\circ} \mathrm{C}$ and the relative viscosity of the supernatant was immediately measured at room temperature using a Baker's "Jelmeter" viscosity pipette.

The apparent nutrient digestibilities were calculated from the ratio between the nutrients of interest and the marker in feed and excreta, respectively. Apparent crude protein digestibility was calculated using the $\alpha$-amino nitrogen method $(\mathrm{N}$ $\left.\alpha-\mathrm{NH}_{2}\right)($ Barteczko et al., 1993).

The chemical composition of wheat grain, diets and excreta was determined according to AOAC (2000), while $\alpha$-amino nitrogen in excreta was measured according to Barteczko et al. (1993). Neutral detergent fibre (NDF) and aciddetergent fibre (ADF) were determined according to Georing and Van Soest (1970) using the Ankom ${ }^{220}$ (Ankom Technology) apparatus. Insoluble dietary fibre (IDF) and soluble dietary fibre (SDF) were determined by an enzymatic method (Englyst and Cummings, 1988). The content of gross energy (GE) in diets and excreta was measured using a Parr adiabatic oxygen bomb calorimeter (KL-10, Precyzja, Bydgoszcz, Poland).

\section{Statistical analysis}

Data were evaluated statistically by one-way analysis of variance using SAS software (1996). Differences between treatment means were tested using Duncan's multiple range test.

\section{RESULTS}

The weight of 1000 grains was from $38 \mathrm{~g}$ in Rysa cv. to $52 \mathrm{~g}$ in Mikula cv. The content of basic nutrients, as well as detergent fibre fractions and dietary fibre fractions differed among cultivars (Table 1). The content of crude protein was 
highest in Rysa cv., lowest in Torka and Turnia cvs., while the content of crude fat was also highest in Rysa cv. and lowest in Torka cv. As all diets contained the same amount of wheat and remaining components, the nutrient content in the diets reflected that of the used wheat cultivars (Table 2).

There was no mortality during the experiment. The wheat cultivar used in the diets did not affect feed intake or BWG, while FCR was better on diets with Turnia, Zebra, Vinjett and Torka cvs., worse on diets with Satyna, Bombona, Bryza and Mikula cvs. (Table 3). The apparent protein digestibility of the diet

Table 3. Performance of broiler chickens fed diets containing different wheat cultivars (14-42 day of age)

\begin{tabular}{lccccccccccc}
\hline \multirow{2}{*}{ Item } & \multicolumn{10}{c}{ Dietary treatment - wheat cultivar } \\
\cline { 2 - 11 } & Zebra & Bryza & Vinjett & Torka & Rysa & Mikula & Turnia & Satyna Bombona & SEM \\
\hline $\begin{array}{c}\text { Initial body } \\
\text { weight, kg }\end{array}$ & 0.42 & 0.43 & 0.43 & 0.43 & 0.43 & 0.43 & 0.43 & 0.43 & 0.44 & 0.00 \\
$\begin{array}{c}\text { Body weight } \\
\text { gain (BWG), kg }\end{array}$ & 2.18 & 2.08 & 2.25 & 2.34 & 2.20 & 2.03 & 2.29 & 2.17 & 2.10 & 0.03 \\
$\begin{array}{c}\text { Feed intake, kg } \\
\begin{array}{c}\text { FCR, kg feed/ } \\
\text { kg BWG }\end{array}\end{array}$ & 4.71 & 4.76 & 4.85 & 5.03 & 4.88 & 4.65 & 4.86 & 5.01 & 4.83 & 0.04 \\
\hline
\end{tabular}

a,b means in rows with different letters differ significantly at $\mathrm{P}<0.05$

with Satyna cv. was highest, followed by Torka, Turnia and Mikula cvs., while that of the diet with Bombona cv., lowest $(\mathrm{P}<0.05)$. The apparent digestibility of $\mathrm{N}$-free extractives (NFE) did not differ among diets (Table 4). Nitrogen retention

Table 4. Apparent total tract digestibility of dietary crude protein (ADP) and nitrogen-free extractives (ADNFE), nitrogen retention (NR), organic matter (OMR) retention (in \%), apparent metabolizable energy $\left(\mathrm{AME}_{\mathrm{N}}, \mathrm{MJ} / \mathrm{kg}\right)$ and energy metabolizability $\left(\mathrm{AME}_{\mathrm{N}} / \mathrm{GE}, \%\right)$ measured in balance experiment

\begin{tabular}{|c|c|c|c|c|c|c|c|c|c|c|}
\hline \multirow{2}{*}{ Item } & \multicolumn{9}{|c|}{ Dietary treatment - wheat cultivar } & \multirow[b]{2}{*}{ SEM } \\
\hline & Zebra & Bryza & Vinjett & Torka & Rysa & Mikula & Turnia & Satyna & Bombona & \\
\hline ADP & $85.0^{\mathrm{d}}$ & $73.3^{b}$ & $80.1^{\mathrm{c}}$ & $81.3^{\mathrm{cd}}$ & $69.6^{\mathrm{ab}}$ & $81.0^{\mathrm{cd}}$ & $81.1^{\mathrm{cd}}$ & $84.7^{\mathrm{d}}$ & $66.2^{\mathrm{a}}$ & 1.33 \\
\hline ADNFE & 92.6 & 91.6 & 93.1 & 93.1 & 94.6 & 92.4 & 93.6 & 92.1 & 93.5 & 0.27 \\
\hline NR & $52.2^{\mathrm{ab}}$ & $43.1^{\mathrm{a}}$ & $54.9^{\mathrm{ab}}$ & $51.1^{\mathrm{ab}}$ & $50.0^{\mathrm{ab}}$ & $59.5^{\mathrm{b}}$ & $59.8^{\mathrm{b}}$ & $58.9^{\mathrm{b}}$ & $42.9^{\mathrm{a}}$ & 1.76 \\
\hline OMR & $77.2^{\mathrm{ab}}$ & $74.5^{\mathrm{a}}$ & $78.6^{\mathrm{ab}}$ & $81.4^{\mathrm{b}}$ & $81.0^{\mathrm{b}}$ & $79.6^{\mathrm{b}}$ & $81.4^{\mathrm{b}}$ & $77.4^{\mathrm{ab}}$ & $76.4^{\mathrm{ab}}$ & 0.63 \\
\hline $\mathrm{AME}_{\mathrm{N}}$ & 12.2 & 12.3 & 12.6 & 12.4 & 12.8 & 12.8 & 12.8 & 12.1 & 12.2 & 0.12 \\
\hline $\mathrm{AME}_{\mathrm{N}} / \mathrm{GE}$ & 76.2 & 77.2 & 78.4 & 76.8 & 78.1 & 80.1 & 79.2 & 76.3 & 77.7 & 0.79 \\
\hline
\end{tabular}

a,b means in rows with different letters differ significantly at $\mathrm{P}<0.05$

in chickens fed diets containing Bombona and Bryza cvs. was lower $(\mathrm{P}<0.05)$ than in chickens fed diets with Satyna, Turnia and Mikula cvs. $(\mathrm{P}<0.05)$. Apparent 
metabolizable energy and energy metabolizability did not differ among groups (Table 4).

The wheat cultivars used in the diets had no influence on gizzard weight, ileum length or jejunal digesta $\mathrm{pH}$, while the jejunum was longer in birds fed diets with Bryza and Zebra cvs. in comparison with Mikula and Rysa cvs. (Table 5). The viscosity of jejunal digesta was higher in birds fed diets with Bryza and Satyna cvs. in comparison with diets containing Turnia, Bombona, Vinjett and Zebra cvs. $(\mathrm{P}<0.01)$. The performance data were not significantly correlated with the content of dietary fibre in wheat or with the viscosity of digesta.

Table 5. Effects of diet on $\mathrm{pH}$ and viscosity (in mPass) of jejunal digesta, length of jejunum and ileum $(\mathrm{cm})$ and gizzard weight, $\mathrm{g}$

\begin{tabular}{lccccccccccc}
\hline \multirow{2}{*}{ Item } & \multicolumn{8}{c}{ Dietary treatment - wheat cultivar } \\
\cline { 2 - 12 } & Zebra & Bryza & Vinjett & Torka & Rysa & Mikula & Turnia & Satyna & Bombona SEM \\
\hline Jejunal digesta & & & & & & & & & & & \\
pH & 5.98 & 6.13 & 5.90 & 5.99 & 6.02 & 5.94 & 5.95 & 6.20 & 5.97 & 0.03 \\
viscosity & $3.07^{\mathrm{A}}$ & $4.69^{\mathrm{B}}$ & $2.92^{\mathrm{A}}$ & $3.11^{\mathrm{A}}$ & $3.04^{\mathrm{A}}$ & $3.58^{\mathrm{AB}}$ & $2.70^{\mathrm{A}}$ & $4.61^{\mathrm{B}}$ & $2.70^{\mathrm{A}}$ & 0.19 \\
Jejunum, cm & $112^{\mathrm{b}}$ & $113^{\mathrm{b}}$ & $104^{\mathrm{ab}}$ & $109^{\mathrm{ab}}$ & $102^{\mathrm{a}}$ & $101^{\mathrm{a}}$ & $111^{\mathrm{ab}}$ & $106^{6^{\mathrm{b}}}$ & $108^{\mathrm{ab}}$ & 1.05 \\
Ileum, cm & 78.1 & 74.6 & 73.3 & 76.4 & 70.2 & 71.1 & 73.7 & 74.4 & 71.4 & 0.91 \\
Gizzard, g & 34.6 & 38.1 & 38.6 & 35.7 & 34.9 & 33.4 & 37.2 & 35.5 & 36.9 & 0.43 \\
\hline
\end{tabular}

a,b,A,B means in rows with different letters differ significantly at: ${ }^{\mathrm{a}, \mathrm{b}} \mathrm{P}<0.05{ }^{\mathrm{A}, \mathrm{B}} \mathrm{P}<0.01$

\section{DISCUSSION}

Wheat AME values were shown to range in Australia from 10.5 to $15.5 \mathrm{MJ} / \mathrm{kg}$ (Mollah et al., 1983), in Canada from 11.9 to $14.4 \mathrm{MJ} / \mathrm{kg}$ (Classen et al., 1995), while in Europe some authors found no difference in the AME of different wheat cultivars (Steenfeldt, 2001; Pirgozliev, 2003). According to (Classen et al., 1995) the soluble non-starch carbohydrate (NSP) fraction has a negative relationship with AME of different wheat genotypes and mostly affects digesta viscosity. Carré et al. (2002) reported that in broilers, high digesta viscosity negatively affected lipid and starch digestibility, while the digestibility of protein of different wheat cultivars was similar. Carré et al. (2007) stressed that the viscosity of wheat in the chicken digestive tract results from a combination of several variables, among others from the physico-chemical characteristics of soluble NSP, endogenous xylanases, activity of proteinaceaous inhibitors, and technological treatment (grinding, pelleting).

In the current study no significant differences in $\mathrm{AME}_{\mathrm{N}}$ value between diets based on different wheat cultivars were found, similarly as in experiments by Steenfeldt (2001) and Pirgozliev (2003). The viscosity of jejunal digesta was 
significantly different between groups. In chickens fed diets with Zebra, Vinjett, Torka, Rysa, Turnia and Bombona cvs. jejunal digesta viscosity was lower (from 2.7 to $3.1 \mathrm{mPas} s$, respectively) than in chickens fed Bryza and Satyna cvs. (4.65 $\mathrm{mPas} \cdot \mathrm{s}$, on average). The range between wheat cultivars reported by Campbell et al. (1995) was much greater - from 4.5 to $33.2 \mathrm{mPas} \cdot \mathrm{s}$. In the current study, FCR in groups fed diets with 4 wheat cultivars of lower viscosity (Zebra, Vinjett, Torka and Turnia) was $6 \%$ better than on the remaining 5 cultivars. Viscosity problems connected with feeding wheat are less common than with barley or rye (Svihus et al., 2000) and can be reduced by xylanase supplementation (Choct et al., 1999). In the current study, lower apparent protein digestibility of wheat cvs. also resulted in worse FCR.

Campbell et al. (1995) found a negative relationship of soluble NSP content and digesta viscosity with AME value, while Dusel et al. (1997) found a high correlation between IDF content in diets and intestinal viscosity in chickens, but in the present experiment neither correlation achieved statistical significance. Hetland and Choct (2003) claimed that the IDF fraction stimulated growth of the gizzard in chickens, but this was not confirmed in the present study. Modern broilers genetically selected for high feed efficiency may not show optimal digestibility of nutrients when fed on wheat diets, so the nutritional potential of wheat cultivars in poultry feeding should be investigated. It seems, however, that viscosity in the broiler chicken intestinal tract as well as nutritional value of different wheat cultivars cannot be predicted by analysis of particular dietary fibre or detergent fibre fractions.

\section{REFERENCES}

AOAC, 2000. Association of Official Analytical Chemists, Official Methods of Analysis. 17th Edition. Washington, DC

Barteczko J., Kamiński J., Marszałek A., 1993. Effect of methods of determination of faecal and urinary nitrogen on the value of apparent protein digestibility coefficient in laying hens of low or high productivity (in Polish). Zesz. Nauk. PTZ 8, 188-194

Carré B., Idi A., Maisonnier S., Melcion J.P., Oury F.-X., Gomez J., Pluchard P., 2002. Relationship between digestibilities of food components and characteristics of wheats (Triticum aestivum) introduced as the only cereal source in a broiler chicken diet. Brit. Poultry Sci. 43, 404-415

Carré B., Mignon-Grasteau S., Péron A., Juin H., Bastianelli D., 2007. Wheat value: improvements by feed technology, plant breeding and animal genetics. World Poultry Sci. J. 63, 585-596

Choct M., Hughes R.J., Bedford M.R., 1999. Effects of xylanase on individual bird variation, starch digestion throughout the intestine, and ileal and caecal volatile fatty acid production in chickens fed wheat. Brit. Poultry Sci. 40, 419-422 
Classen H.L., Scott T.A., Irish G.G., Hucl P., Swift M., Bedford M.R., 1995. The relationship of chemical and physical measurements to the apparent metabolizable energy (AME) of wheat when fed to broiler chickens with and without a wheat enzyme source. Proceedings of $10^{\text {th }}$ European Symposium on Poultry Nutrition, Antalya (Turkey), pp. 169-175

Dusel G., Kluge H., Gläser K., Simon O., Hartmann G., Lengerken J.V., Jeroch H., 1997. An investigation into the variability of extract viscosity of wheat - relationship with the content of non-starch polysaccharide fractions and metabolisable energy for broiler chickens. Arch. Anim. Nutr. 50, 121-135

Englyst H.N., Cummings J.H., 1988. Improved method for measurement of dietary fibre as nonstarch polysaccharides in plant food. J. Assn. Off. Anal. Chem. 71, 808-814

Goering H., Van Soest P., 1970. Forage Fiber Analysis. USDA Agriculture Handbook. 379, 1-20

Hetland H., Choct M., 2003. Role of insoluble non-starch polysaccharides in poultry nutrition. Proceedings of $14^{\text {th }}$ European Symposium on Poultry Nutrition, Lillehammer (Norway), pp. 64-69

McCracken K. J., Quintin G., 2000. Metabolisable energy of diets and broiler performance as affected by wheat specific weight and enzyme supplementation. Brit. Poultry Sci. 41, 332-342

Mollah Y., Bryden W.L., Wallis I.R., Balnave D., Annison E.F., 1983. Studies on low metabolisable energy wheats for poultry using conventional and rapid assay procedures and the effects of processing. Brit. Poultry Sci. 24, 81-89

Pirgozliev V.R., Birch C.L., Rose S.P., Kettlewell P.S., Bedford M.R., 2003. Chemical composition and the nutritive quality of different wheat cultivars for broiler chickens. Brit. Poultry Sci. 44, 464-475

Smulikowska S., Rutkowski A. (Editors), 2005. Recommended Allowances and Nutritive Value of Feedstuffs. Poultry Feeding Standards (in Polish). $4^{\text {th }}$ Edition. The Kielanowski Institute of Animal Physiology and Nutrition, PAS, Jabłonna (Poland)

SAS, 1996. User's Guide: Statistics. Release 6.12. SAS Institute Inc. Cary, NC

Steenfeldt S., 2001. The dietary effect of different wheat cultivars for broiler chickens. Brit. Poultry Sci. 42, 595-609

Svihus B., Edvardsen D.H., Bedford M.R., Gullord M., 2000. Effect of methods of analysis and heat treatment on viscosity of wheat, barley and oats. Anim. Feed. Sci. Tech. 88, 1-12 